\title{
Growth rate of the cell populations of the rat sublingual gland during the early postnatal period
}

\section{Taxa de crescimento das populações celulares da glndula sublingual de rato durante o período posnatal inicial}

Karen Fernandes MADI

Recipient of CNPq fellowship, Department of Biological Sciences, Laboratory of Histology - Dentistry School of Bauru, University of São Paulo, Brazil.

Tania Mary CESTARI

Graduate in Biological Sciences, Department of Biological Sciences, Laboratory of Histology - Dentistry School of Bauru, University of São Paulo, Brazil.

Rumio TAGAA

DDS. PhD, Full Professor of Department of Biological Sciences, Laboratory of Histology - Dentistry School of Bauru, University of São Paulo, Brazil.

\begin{abstract}
The development of the rat sublingual gland during the first month of postnatal life was analyzed by morphometry. The absolute number of cells in the various morphological glandular compartments - mixed acini with serous demilunes, intercalated ducts, striated ducts and stroma - was determined by the Aherne II morphometric method for particle counting. The data of fresh glandular volume and the number of cells were analyzed by linear, exponential and parabolic regression, with the best fits being obtained with the linear equation. Based on these equations, the growth rate of glandular volume and of each cell population was calculated. Glandular volume increased about 12-fold during the period from 2 to 30 days of postnatal life, corresponding to a rate of $1.34 \mathrm{~mm}^{3} / \mathrm{day}$. This volumetric growth of the gland was mainly due to significant 16-, 10-, 4-, 7and 8 -fold increases in the absolute number of mucous acinar, serous demilune, intercalated duct, striated duct and stromal cells, corresponding to a growth rate of $301 \times 10^{3}, 228 \times 10^{3}, 19 \times 10^{3}, 54 \times 10^{3}$ and $247 \times 10^{3}$ cells/day, respectively. Based on the present results, we conclude that the mucous and serous cell populations of the mixed acini grew at a rate close to that of stromal cells, but considerably higher than that obtained for the intercalated duct and striated duct populations, with the lowest growth rate being observed for the intercalated duct cell population.
\end{abstract}

\section{UNITERMS}

Development, sublingual gland, proliferation, rat.

\section{INTRODUCTION}

In contrast to the high degree of immaturity of the rat parotid and submandibular glands at birth, its sublingual glands already consist of the definitive, although morphologically still immature, epithelial structures - i.e., mixed acini, intercalated ducts, striated ducts and excretory ducts ${ }^{15}$. Thus, cytodifferentiation of the cells of these structures occurs during the fetal period ${ }^{17,20,21,27}$.

The fresh mass of the rat sublingual gland increases by more than $1000 \%$ during the first thirty days of postnatal life, and its parenchymatous structures develop morphologically until reaching a pattern similar to that of the adult animal at the end of this period ${ }^{15,26}$.

Biochemical, morphometric and autoradiographic studies carried out in our laboratory have shown that the growth of this gland is mainly the result of an increase in the absolute number of cells due to proliferative activity in the various glandular morphological compartments ${ }^{7,23,26}$. Although the proliferation rate and the cell duplication time have been determined for each compartment of the rat 
sublingual gland ${ }^{24}$, the growth rate (velocity of growth) of these cell populations during this period of ontogenetic development is still unknown.

In this study, we determined the evolution of glandular volume and of the number of cells in each glandular compartment during the first thirty days of postnatal life. Based on the equations that best fitted these data to age in days, the growth rate (velocity of growth) of glandular volume and of each cell population during this period was calculated.

\section{Material and Methods}

Twenty four Wistar rats (Rattus novergicus) of both sexes 2,5,10,15,20 and thirty days old (four rats/age group) were used. The litters remained with theirs mothers until day twenty of postnatal life. The pregnant female, the dams with litters and weaned litters were treated with water and pelleted chow ad libitum.

The glands were always collected between 10:00 and 12:00 a.m. to avoid circadian variations. The rats were killed by excessive ether inhalation and the body mass of each animal was determined. The sublingual glands of each rat were carefully removed and immediately weighed. The gland were fixed in Helly's solution for 3 hours, washed overnight in running water, dehydrated in ethanol, cleared in xylene and embedded in paraffin. Alternate sections $5 \mu \mathrm{m}$ thick were obtained at of $50 \mu \mathrm{m}$ intervals of each rat and stained with hematoxylin and eosin.

\section{Determination of the processed gland volume}

The volume of the sublingual gland $(\mathrm{V})$ was calculated using the formula $\mathrm{V}=\mathrm{m} / \delta$, where $\mathrm{m}=$ fresh gland mass in $\mathrm{mg}$ and $\mathrm{d}=$ gland density in $\mathrm{mm} 3 / \mathrm{mg}$. Knowing the fresh gland volume $(\mathrm{V})$ and correction factor (Sf) for the shrinkage caused by histological processing, the processed gland volume $(\mathrm{Vp})$ was calculated by formula $\mathrm{Vp}=\mathrm{V}$ x Sf. The gland density $(\delta)^{*}$ was determinated by measuring glands of 6 young adults rats, using Mettler Toledo scale with accessories for density determination and the correction factor (Sf)* for the retraction caused by laboratorial procedures was evaluated in gland of other six young adults rats, using the method of Taga \& $\operatorname{Sesso}^{23}$ (1978).

\section{Determination of absolute number cells}

The morphometric counting were made using a Zeiss 8x Kpl eyepiece containing an integration graticle with ten parallel line and hundred points symmetrically distributed in quadrangular area, and a 100x oil immersion objective in an Olympus light microscope. In forty histological fields per rat obtained by systematic randomization, we scored the number of nucleus images (n) of each cell type and the number of intersections (c) of the contours of the nuclei with the lines of the graticle. The absolute number of each cell type in the gland $(\mathrm{Ni})$ was calculated using the formula $\mathrm{Ni}=\mathrm{Ni} \frac{2 \mathrm{n} \cdot \mathrm{Vp}}{\mathrm{A}[(\mathrm{c} / \mathrm{n}) \cdot \mathrm{d}+2 \mathrm{t}]}\left(\right.$ Aherne \& Dunnill $\left.{ }^{1}, 1982\right)$, where $\mathrm{Vp}=$ gland processed volume, $\mathrm{d}=$ distance between graticle lines, $\mathrm{A}=$ total area examined and $\mathrm{t}=$ section thickness

The number of 40 histological fields per rat was assessed using the multiple $\mathrm{X}^{2}$ sample homogeneity test with probability level of $5 \%{ }^{24}$.

\section{Statistical analysis}

The data of gland volume and number of cells for each age group were compared with those of the other groups by analysis of variance (ANOVA) and pairwise multiple comparison procedures (Student-Newman-Keus test) using version 1.0 of the Sigma Stat software (Jadel Scientific) for Windows. These data were submitted to fitting by linear, exponential and parabolic regression with the Arcus Professional Statistical Analysis software, version 2.0 XTc. The goodness of fit was assessed using the coefficient of determination $\left(\mathrm{r}^{2}\right)$

\section{Results}

The evolution of glandular volume and of the number of cells in the different morphological compartments of the rat sublingual gland during the first month of postnatal life are shown in Table 1 and the best fit equations obtained for the data are presented in Table 2. Glandular volume markedly increased about 12 -fold during the period studied, from $3.6 \mathrm{~mm}^{3}$ at day 2 to $42.4 \mathrm{~mm}^{3}$ at day 30 of development. The linear equation mathematically representing the evolution of glandular volume as a function of age in days was $\mathrm{Y}=-2.55+1.34 \mathrm{x}\left(\mathrm{r}^{2}=0.90\right)$, and the growth rate calculated was $1.34 \mathrm{~mm}^{3} /$ day. 
All cell populations played a significant role in this gland growth, markedly due to proliferative activity. In this respect, the number of mucous, serous demilune, intercalated duct, striated duct and stromal cells increased, respectively, about 16-fold (from $57.4 \times 10^{4}$ to $910.4 \times 10^{4}$ cells), 10 -fold (from $68.5 \times 10^{4}$ to $718.8 \times 10^{4}$ cells), 4 -fold (from $18.9 \times$ $10^{4}$ to $79.4 \times 10^{4}$ cells), 7 -fold (from $26.1 \times 10^{4}$ to $181.8 \times 10^{4}$ cells) and 8-fold (from $96.7 \times 10^{4}$ to
$769.6 \times 10^{4}$ cells). The linear equations that mathematically express this cell population growth are shown in Table 2.

The cell population growth rate or velocity of cell accumulation calculated based on the respective equation was $301 \times 10^{3}, 228 \times 10^{3}, 19 \times 10^{3}$, $54 \times 10^{3}$ and $247 \times 10^{3}$ cells/day for the mucous, serous demilune, intercalated duct, striated duct and stromal cell populations, respectively.

Table 1 - The evolution of glandular volume and of the number of cells in the different morphological compartments of the rat sublingual gland during the first month of life

\begin{tabular}{lcccccc}
\hline \multicolumn{1}{c}{ PARAMETER } & \multicolumn{7}{c}{ PERIOD IN DAYS } \\
\hline & $\mathbf{2}$ & $\mathbf{5}$ & $\mathbf{1 0}$ & $\mathbf{1 5}$ & $\mathbf{2 0}$ & $\mathbf{3 0}$ \\
Gland volume $\left(\mathbf{m m} \_\right)$ & $3.58 \pm 0.045$ & $6.21 \pm 0.786$ & $9.52 \pm 0.323$ & $11.11 \pm 0,403$ & $21.84 \pm 1.576$ & $42.42 \pm 1.872$ \\
\hline Cell Number (x104) & & & & & & \\
Mucous cells & $57.4 \pm 2.51$ & $146.5 \pm 24.86$ & $228.3 \pm 5.86$ & $304.7 \pm 11.29$ & $564.1 \pm 12.63$ & $910.4 \pm 33.34$ \\
Serous demilune cells & $68.5 \pm 4.62$ & $167.0 \pm 15.72$ & $206.2 \pm 10.81$ & $284.3 \pm 11.17$ & $478.7 \pm 6.06$ & $718.8 \pm 46.3$ \\
\hline Intercalated duct cells & $18.9 \pm 1.33$ & $47.4 \pm 6.34$ & $53.9 \pm 6.63$ & $53.7 \pm 3.10$ & $72.7 \pm 3.5$ & $79.4 \pm 6.46$ \\
Striated duct cells & $26.1 \pm 1.87$ & $54.5 \pm 8.76$ & $55.3 \pm 8.19$ & $71.3 \pm 5.27$ & $123.6 \pm 12.39$ & $181.8 \pm 11.68$ \\
\hline Stromal cells & $96.7 \pm 4.82$ & $172.9 \pm 34.72$ & $225.2 \pm 11.41$ & $341.2 \pm 26.97$ & $569.0 \pm 36.28$ & $769.6 \pm 70.68$ \\
\hline
\end{tabular}

* Mean \pm standard error of mean

Table 2 - Equations obtained by regression analysis for cell number of each compartment of sublingual gland from 2 to $\mathbf{3 0}$ days of postnatal period

\begin{tabular}{lcc}
\hline \multicolumn{1}{c}{ Dimension } & Equation & $\mathbf{r}^{2}$ \\
\hline Glandular Volume $\left(\mathrm{mm}^{3}\right)$ & $\mathrm{y}=-2.55+1.34 \mathrm{x}$ & 0.89 \\
\hline Number of Cells $\left(\mathrm{x} 10^{4}\right)$ & & \\
\hline Mucous cells & $\mathrm{y}=-43.30+30.14 \mathrm{x}$ & 0.95 \\
\hline Serous Demilune cells & $\mathrm{y}=9.29+22.78 \mathrm{x}$ & 0.94 \\
\hline Intercalated duct cells & $\mathrm{y}=28.71+1.88 \mathrm{x}$ & 0.69 \\
\hline Striated duct cells & $\mathrm{y}=11.96+5.38 \mathrm{x}$ & 0.87 \\
\hline Stromal cells & $\mathrm{y}=24.80+24.71 \mathrm{x}$ & 0.90 \\
\hline
\end{tabular}




\section{Discussion}

The sublingual gland of the laboratory albino rat, like the similar human gland, is classified histologically into a mixed, predominantly mucous, tubuloacinar gland. This gland consists of terminal secretory units which show a volumetric predominance of mucous cells over serous demilune cells, and a highly branched system of intercalated, striated and excretory ducts ${ }^{10,14,18}$.

The mucous cells possess a basal flattened nucleus, basal rough endoplasmic reticulum and weakly electron-dense mucus granules containing the mucins called sublingual mucins ${ }^{27,28}$, filling almost the entire cytoplasm ${ }^{10,14,18}$. In contrast, the serous demilune cells show a central spherical nucleus, basal endoplasmic reticulum and apical electrondense secretory granules ${ }^{14,18}$ containing proteins called common salivary protein 1 (CSP-1) and neonatal submandibular gland proteins $\mathrm{B}$ and $\mathrm{D}$ (SMGB and SMGD) $)^{4-6,12,16,27,28}$.

All these structures of the rat sublingual gland differentiate during the last days of prenatal development ${ }^{3,17,19,27}$. Thus, all epithelial cell types characteristic of the adult gland are already present at birth, although they are still immature ${ }^{3,15,24,26}$.

The fresh mass of the rat sublingual gland shows a marked increase of more than $1000 \%$ during the first 30-40 days of postnatal life $^{24}$, following an isometric pattern of allometric growth ${ }^{13}$. The secretory, myoepithelial and ductal cells of the gland mature morphologically until reaching the adult pattern at the end of this period ${ }^{26}$.

In the present study, glandular volume increased about 12 -fold between day two and day thirty of postnatal life, corresponding to a growth rate of $1.34 \mathrm{~mm}^{3} /$ day calculated based on the $\mathrm{Y}=0.55+$ $1.34 \mathrm{x}$ equation. It should be pointed out that all morphological glandular compartments - mucous portion of the tubules and acini, serous demilunes, ducts and stroma - participate in this volumetric growth of the gland by increasing significantly their absolute volume ${ }^{13}$.

Studies using biochemical analysis of total $\mathrm{DNA}^{7}$, morphometry for the determination of the total number of cells and the number of cells in each morphological compartment ${ }^{24}$, and ${ }^{3} \mathrm{H}$-thymidine radioautography for the determination of the proliferation rate in the gland and in its various glandular compartments ${ }^{24,26}$ have shown that this volumetric gain is mainly due to proliferative activity, notably of their secretory cells. Using the last method, Taga \& $\mathrm{Sesso}^{24}$ (1998) obtained proliferation rates, i.e., ${ }^{3} \mathrm{H}$-thymidine labeling indices, of $9.5,5.8,7.2,3.3$ and $4.3 \%$ for the mucous, serous demilune, intercalated duct, striated duct and stromal cell populations, respectively, during the period from 2 to 30 days of postnatal development life. In addition, the duplication time of the number of cells in the various compartments, which gives an indirect idea of the numerical compartmental growth rate, was 7.5, 9.0, 16.9, 10.8 and 9.5 days, respectively.

In the above cited work ${ }^{24}$, it was observed correlation between proliferative activity and the duplication time for the mucous, demilune serous and stromal cells, however, this correlation did not occur for intercalated and striated duct cells. The intercalated duct cells showed the second highest proliferative activity but a lowest cell accumulation rate (the longest duplication time) and the striated duct cells exhibited the lowest proliferative activity but a highest rate of cell accumulation (the third shortest duplication on time), markedly higher than that in the intercalated ducts, indicating that the cells produced in intercalated ducts migrate to the striated ducts.

The number of cells obtained in the present study for the different morphological compartments was slightly higher for all age groups than those reported in the investigation cited above. The growth rate or velocity of growth of the various cell populations calculated based on the respective regression equation was, in decreasing order, $301 \times 10^{3}, 247 \mathrm{x}$ $10^{3}, 228 \times 10^{3}, 54 \times 10^{3}$ and $19 \times 10^{3}$ cells/day for the acinar, stromal, serous demilune, striated duct and intercalated duct cells, respectively, i.e., both secretory cells and stromal cells showed the highest velocities of growth during the first month of postnatal development of the rat sublingual gland. On the other hand, intercalated duct cells presented the lowest velocity, which was $65 \%$ lower than that observed for the striated duct cell population.

Since, Taga \& $\mathrm{Sesso}^{24}$ showed that the proliferation rate of intercalated duct cells is quite high, i.e., more than twice that of striated duct cells during the same period, the results described here are also favorable to the hypothesis proposed in other studies $^{2,8,9,11,22,25,29}$ that, during the postnatal development of the major salivary glands of the rat and 
mouse, the intercalated ducts produce excess cells which migrate to the striated ducts.

\section{Conclusion}

Based on the results described here, we conclude that the mucous and serous demilune cell populations of the rat sublingual gland during postnatal development grew at a rate close to that of stromal cells, but considerably higher than that of the intercalated duct and striated duct cell populations, with the lowest growth rate being observed for the intercalated duct cell population.

\begin{abstract}
Resumo
O desenvolvimento da glândula sublingual do rato durante o primeiro mês de vida pós-natal foi analisado pela morfometria. O número absoluto de células nos vários compartimentos morfológicos glandulares - ácinos mistos com demiluas serosas, ductos intercalares, ductos estriados e estroma - foi determinado usando o método morfométrico II de Aherne de contagem de partículas. Os dados de volume glandular à fresco e de número de células foram analisados pela regressão linear, exponencial e parabólica, sendo que os melhores ajustes foram obtidos pela equação linear $(Y=a+b x)$. De posse dessas equações calculamos a velocidade de crescimento de volume glandular e de cada população celular. $O$ volume glandular cresceu ao redor 12 vezes no período de 2 a 30 dias de vida pós-natal, a uma velocidade de $1,34 \mathrm{~mm}^{3} /$ dia. Esse crescimento volumétrico da glândula se deveu em grande parte ao aumento significante ao redor de 16 vezes, 10 vezes, 4 vezes, 7 vezes e 8 vezes, respectivamente, no número absoluto de células acinosas mucosas, das demiluas serosas, dos ductos intercalares, dos ductos estriados e estromais, a uma velocidade, respectivamente, de $301 \times 10^{3}$ células/dia, $228 \times 10^{3}$

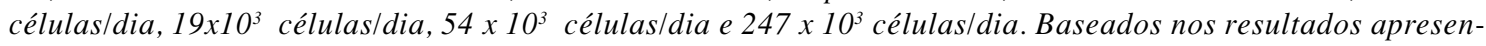
tados aqui, concluímos que durante o desenvolvimento pós-natal das glândulas sublinguais do rato, as populações de células mucosas e serosas dos ácinos mistos crescem com velocidades próximas a das células estromais, mas sensivelmente maiores do que as das populações dos ductos intercalares e dos ductos estriados, sendo que a população que exibe a menor velocidade de crescimento é a dos ductos intercalares.
\end{abstract}

\title{
UNITERMOS
}

Desenvolvimento; glândula sublingual; proliferação; rato

\section{References}

1. Aherne W, Dunnil MS. Morphometry. London : Edward Arnold; 1982.

2. Alvares EP, Sesso A. Cell proliferation, differentiation and transformation in rat submandibular gland during early postnatal growth: a quantitative and morphological study. Arch Histol Jap, 1975; 38:177-208.

3. Ball WD. Development of the rat salivary glands. IV. Amylase and ribonuclease activity during embryonic and neonatal development of the parotid and submaxillary glands. Dev Biol 1974 Dec;41(2):267-77.

4. Ball WD, Hand AR, Johnson AO. (1988) Secretory proteins as markers for cellular phenotypes in rat salivary glands. Dev Biol 1988; 125:265-79.

5. Ball WD, Hand AR, Moreira JE. A neonatal secretory protein associated with secretion granule membranes in developing rat salivary glands. J Histochem Cytochem 1991 Dec;39(12):1693-706.

6. Ball WD, Hand AR, Moreira JE, Iversen JM, Robinovitch MR. The B1-immunoreactive proteins of the perinatal submandibular gland: similarity to the major parotid gland protein, RPSP. Crit Rev Oral Biol Med 1993; 4(3-4):517-24.
7. Barbosa DB, Hassunuma RM. Taga R. Estudo morfométrico e bioquímico do crescimento das glândulas sublinguais do rato durante a vida pós-natal. Rev Ciênc Bioméd 1997; 18:83-94.

8. Chai Y, Klauser DK, Denny PA, Denny PC. Proliferative and structural differences between male and female mouse submandibular glands. Anat Rec 1993 Feb;235(2):303-11.

9. Chang WWL. Cell population changes during acinus formation in the postnatal rat submandibular gland. Anat Rec 1974; 178:187-201.

10.Culp DJ. Grham LA. Latchney LR. Rat sublingual gland as a model to study gandular mucous cell secretion. Am J Physiol 1991; 260:C1233-44.

11. Denny PC, Chai Y, Klauser DK, Denny PA. Parenchymal cell proliferation and mechanisms for maintenance of granular duct and acinar cell populations in adult male mouse submandibular gland. Anat Rec 1993; 235:475-85.

12. Girard LR, Castle AM, Hand AR, Castle JD, Mirels L. Characterization of common salivary protein 1 , a product of rat submandibular, sublingual, and parotid glands.J Biol Chem 1993 Dec $15 ; 268(35): 26592-601$.

13. Hassunuma RM. Taga R. Allometric study of the postnatal development of the rat sublingual glands. Okajimas folia Anat Jpn $1996 ; 73: 265-71$. 
14. Leeson CR. Structure of salivary glands. In: Handbook of Physiology. Washington American Physiology Society 1967; 2:463-95.

15. Leeson CR, Both WG. Histological, histochemical and electronmicroscopic observations on the postnatal development of the major sublingual gland of the rat. J Dent Res 1961; 40:838-45.

16. Mirels L, Miranda AJ, Ball WD. Characterization of the rat salivary-gland B1-immunoreactive proteins. Biochem J 1998 Feb 15; 330 ( Pt 1):437-44.

17. Moriguchi K, Yamamoto M, Asano T, Shibata T. Peroxidase activity and cell differentiation in developing salivary glands of the rats. Okajimas Folia Anat Jpn 1995 May;72(1):13-28.

18. Pinkstaff CA The cytology of salivary glands. Int Rev Cytol 1980; 63:141-261.

19. Redman RS, Ball WD. Cytodifferentiation of secretory cells in the sublingual gland of the prenatal rat: a histological, histochemical and ultrastructural study. Am J Anat 1978 Nov;153(3):36789.

20. Redman RS, Ball WD. Differentiation of myoepithelial cells in the developing rat sublingual gland. Am J Anat 1979 Dec;156(4):543-65.

21. Redman RS, Sreebny LM. Proliferative behavior of differentiating cells in the developing rat parotid gland. J Cell Biol 1970 Jul;46(1):81-7.
22. Srinivasan R, Chang WWL. The development of the granular convoluted duct in the rat submandibular gland. Anat Rec 1975; 182: $29-40$.

23. Taga R, Sesso A. Avaliação do número de células de órgãos pela dosagem bioquímica de DNA em homogeneizados por contagem direta através de métodos morfométricos. Ciênc Cult 1978; 30: 1232-6.

24. Taga R, Sesso A. Postnatal development of the rat sublingual glands. A morphometric and radioautographic study. Arch Histol Cytol 1998 Dec;61(5):417-26

25. Taga R, Sesso A. Cell population growth in the rat parotid gland during postnatal development. Arch Oral Biol 2001 Oct;46(10):909-18.

26. Taga R, Sesso A. Ultrastructure of the rat sublingual gland during period of high proliferative activity in postnatal development. Braz J morphol Sci 2002; 19:55-62.

27. Wolff MS, Mirels L, Lagner J, Hand AR. Development of the rat sublingual gland: a light and electron microscopic immunocytochemical study. Anat Rec 2002 Jan 1;266(1):30-42.

28. Watson GE, Latchney LR, Luo W, Hand AR, Culp DJ. Biochemical and immunological studies and assay of rat sublingual mucins. Arch Oral Biol 1997 Feb;42(2):161-72.

29.Zajicek G, Yagil C, Michaeli Y. The streaming submandibular gland. Anat Rec 1985; 213:150-8.

Recebido em: 07/02/03

Aprovado em: 30/03/03

Departamento de Ciências Biológicas - Histologia Faculdade de Odontologia de Bauru - USP

Al. Octávio Pinheiro Brisolla, 9-75

Zip code: 17012-901

Bauru - SP, Brazil

Tel: (14) 2358259

e-mail: cestari@fob.usp.br 